\title{
THE EFFECT OF RETIREMENT ON MALE
}

\author{
MORTALITY
}

\section{QUASI-EXPERIMENTAL EVIDENCE FROM NORWAY}

\begin{abstract}
On average, people who retire earlier die sooner, partly because poor health is an important reason for early retirement. Several theories also predict that retirement is detrimental to health and increases mortality, and that retirement should affect people in different occupations differently. Yet, there is apparently no consensus about the causal relationship between retirement and mortality. We treat a Norwegian pension reform that lowered retirement eligibility age by three years in 1973 as a natural experiment. The reform affected virtually the entire elderly working population. We estimate the long-term effect of retirement age and the short-term effect of retirement eligibility using instrumental variables and difference-in-differences methods. The results show that neither earlier retirement nor retirement eligibility affect male mortality substantially. Analyses by educational level and occupational groups show no occupational or educational differences in the effect of retirement on mortality. We also argue that the 1973 reform serves as a critical case; a situation where we should be able to identify an effect if there were one. In other words, this study provides strong evidence that retirement does not have a causal effect on male mortality.
\end{abstract}

Keywords: Aging; Retirement; Mortality; Norway; Policy reform

\section{INTRODUCTION}


Postprint version

In response to ageing populations, several countries have implemented pension reforms that aim to postpone the retirement of elderly workers (OECD 2013). This has spurred renewed interest in the potential health and mortality effects of retirement. Commonly conceptualized as a major life course transition, retiring from gainful employment may increase or reduce stress, provide relief or induce role loss, and either positively or negatively affect people's health behaviors and exposures to workrelated health risks or benefits (see for instance van der Heide et al. 2013; Ekerdt 1987; Minkler 1981).

In this paper, we investigate whether retirement has a causal effect on male mortality by studying a Norwegian pension reform that came into effect in 1973. This reform lowered the eligibility age for old age pensions in the national insurance scheme from 70 to 67 years. We employ Norwegian administrative register data and census data on five full male birth cohorts (born between 1902 and 1906). We then attempt to identify the long-term effect of earlier retirement on mortality between ages 70 and 100, and the short-term effect of retirement eligibility on mortality up to 36 months after the reform. The data further allows us to investigate effect heterogeneity with regard to educational level and occupational groups, to study the temporal profile of the effect in some detail and to study the entire mortality history of the cohorts in question. While the use of a dated reform makes it more difficult to generalize the results to the present, the relatively high baseline mortality in our sample should facilitate the identification of an effect, if there is one. The affected age group is also relevant for present-day and future pension reforms aiming to increase the retirement ages up to and beyond age 70.

\section{THEORETICAL PERSPECTIVES}

Retirement may be motivated by a number of factors. Examples include mandatory retirement ages, poor health, job strain or dissatisfaction, the retirement of ones' partner, and a desire for more leisure time. Depending on the nature of the job one retires from, retirement may in itself be good or bad for one's health. Retiring from a stressful, physically straining or otherwise demanding or unsatisfactory job may be a relief and yield health benefits, while retiring from a job that provides structure, physical activity, cognitive stimuli and/or a social network of colleagues may have adverse health consequences. The potential effect of retirement on mortality could further depend on the health 
Postprint version

behaviors or lifestyle of the retiree. Furthermore, the increased spare time gained by retiring could allow for lifestyle changes that may positively or adversely affect health and mortality risk (Bonsang et al. 2012; van den Bogaard et. al. 2016; van der Heide et al. 2013) including physical activity, changes in diet, and alcohol and cigarette use etc. (Syse et al. 2015). Some may also expect health gains from retirement and thus be motivated to retire earlier (a selection on expected gains).

Several influential gerontological theories have conceptualized retirement as a continuity break or role loss with potentially adverse health consequences. Both the activity theory (Havighurst 1963/2009), the continuity theory (Atchley 1989), the disengagement theory (Cumming and Henry 1961, but see the criticism by Hochschild 1975) and the stressful life event perspective (Daatland and Solem 2000:150; Minkler 1981) can be taken to predict that if retirement affects health and longevity, this effect should be adverse, since major life transitions may induce stress or health deterioration among the elderly. The reason for retirement may also be relevant for the health effects of retirement, as involuntary retirement may induce more stress than voluntary retirement (van der Heide et al. 2013). Also, some people may voluntarily retire to be able to take better care of their health, which could produce a positive health effect from retirement. Atchley (1976) has suggested a temporal effect and conceptualizes (voluntary) retirement as a series of phases. Following retirement, Atchley states that retirees tend to enter a honeymoon phase, enjoying his or her newfound freedom and spare time, spending more time on positive leisure activities. This period is followed by a disenchantment phase, which results from problems adjusting to the life as a retiree and may lead to disappointment, depression and/or physical health deterioration.

Regarding the causal effects of retirement on health, the results are mixed, and studies have found both positive and negative health effects of retirement (see Hagen 2017 for a review). . Investigating the mechanisms linking retirement and health, Eibich (2015) has shown that both factors related to work and lifestyle may be of importance. Grøtting and Lillebø (2017) have shown retirement to be more beneficial for the physical health of individuals with low socioeconomic status while inducing a higher prevalence of depression among individuals with high socioeconomic status. On the other hand, van den Bogaard et. al. (2016) found relative health improvements after retirement to be positively 
Postprint version

associated with psychological job stress but not with physical job demands, suggesting that manual work may not be strongly related to health improvements after retirement.

Taken together, these theories and studies indicate that retirement may have diverging effects for different groups. We may expect retirement to induce stress, depression or other adverse outcomes that may increase mortality, especially among people with high socioeconomic status (i.e. people in highstatus jobs and/or with higher education), especially if retirement is involuntary. However, retirement may be beneficial for people in manual occupations or occupations that otherwise involve health hazards or psychological job stress. The effect may also vary with time since retirement in accordance with the "retirement phases" discussed above. In this article we set out to examine whether the impact of retirement on mortality is positive or negative, short-term or long-term, whether the effect varies between occupational or educational groups, and whether the effect varies with the duration of retirement.

\section{PREVIOUS RESEARCH ON RETIREMENT AND MORTALITY}

\section{THE ASSOCIATION BETWEEN RETIREMENT AND MORTALITY}

Whereas a large number of studies have found early retirement to be associated with higher mortality (recent examples include Bamia et al. 2008; Carlsson et al. 2012; Kühntopf and Tivig 2012; Quaade et al. 2002; Skirbekk et al. 2010; Waldron 2001; Wu et al. 2016), other studies have shown mixed results (Haynes et al. 1978; Litwin 2007; Tsai et al. 2005). Only a few studies have found earlier retirement to be associated with lower mortality (see for instance Brockmann et al. 2009; Munch and Svarer 2005). In a review of the research literature, Shim et al. (2013) conclude that there is strong and sufficient evidence for retirement as a risk factor for mortality.

However, there are possible non-causal explanations for an association between retirement and mortality. Most importantly, the association may be due to some selection process such as selection on expected health gains, or a 'healthy worker' effect ( $\mathrm{Li}$ and Sung 1999; Shim et al. 2013), as poor health predicts early retirement (Blekesaune and Veenstra 2010; Mein et al. 2000; Rice et al. 2011). 
Postprint version

Such health selection into retirement is the main hurdle in studying the health and mortality effects of retirement. While we do not have data on individuals' health, we contribute to the litterature by accounting for health selection into early retirement by way of a natural experiment.

Additionally, this study provides details on the temporal profile of the effect of retirement on mortality by paying special attention to the effect of being retired or eligible for retirement for different durations. While the evidence for such an effect is weak, some studies have suggested that there are retirement phases associated with health and mortality (Ekerdt et al. 1985; Haynes et al. 1978; Kim and Moen 2002; Martin and Doran 1966; Nuttman-Shwartz 2004; Richardson and Kilty 1991; Solem 1987; Westerlund et al. 2009). This notion is, however, contradicted by Van Solinge and Henkens (2008).

\section{THE CAUSAL EFFECT OF RETIREMENT ON MORTALITY}

A limited number of studies have attempted to identify the causal effect of retirement on mortality by accounting for the endogeneity of the retirement decision by exploiting exogenous variation in retirement eligibility induced by early retirement windows,changes in retirement regulations or discontinuities in retirement eligibility. Bingley and Pedersen (2011) and Bloemen et al. (2017) found that early retirement led to reduced mortality among men in blue collar occupations in Denmark and male civil servants in the Netherlands, respectively. Hallberg et al. (2015) also found an early retirement offer to reduce mortality among Swedish male military personnel, apparently due to a reduction in deaths from myocardial infarctions. Kuhn et al. (2010) and Fitzpatrick and Moore (2018) found retirement to increase mortality risk among male Austrian blue-collar workers and US men, respectively, but not among women, likely due to changes in health behavior. Coe and Lindeboom (2008), Hagen (2017), Hernæs et al. (2013) and Lalive and Staubli (2015) found no statistically significant effect of retirement on mortality among US male employees, Swedish female local government workers, Norwegian employees or Swiss women, respectively.

In sum, the evidence for a causal relationship between retirement and mortality is mixed. The different findings may be due to differences in samples, research designs, age groups and country and period contexts, among other things. Table 1 compares the studies mentioned above. In our examination of 
Postprint version

these studies, we have not, however, found any clear patterns that may explain why the results are contradictory.. Further, these studies estimate the effects of retirement on mortality in relatively young samples. It may be that older populations with presumably worse health are more susceptible to the health and mortality effects of major life transitions such as retirement. One of the main contributions of the present paper is thus to examine the causal effect of retirement in an older age group with high baseline mortality. Additionally, the use of register data ensures that we avoid attrition issues, as it enables us to study entire male cohorts, and it allows us to investigate the long-term effects up to age 100. Further, we aim to contribute to the literature by shedding light on whether the effect varies with occupations and educational level, as people in different occupations and with varying levels of education may experience retirement differently. It is worth noting that no studies have found any substantive effects of retirement on female mortality. Unfortunately, we are unable to study the effect of retirement on mortality among women, for reasons discussed below.

\section{TABLE 1 HERE}

\section{THE NORWEGIAN CONTEXT}

Norway is a Nordic welfare state with a relatively generous public pension system and affordable public healthcare (Kjølsrød 2011). Since the end of World War II, Norway has experienced a formidable economic growth (Brathaug and Skoglund 2012), partly facilitated by the discovery of offshore oil reserves in the late 1960s (Eika 2008). Norway is currently ranked fourth in the world on per capita GDP (The World Bank n.d.). The petroleum sector has, in combination with high and progressive taxes, allowed for the development of an expansive public sector with low-priced or freely provided public services, while at the same time maintaining relatively moderate income inequality.

In 1967, a national insurance scheme was introduced which, among other things, provided retirement rights for people aged 70 and older. With a few exceptions, this scheme covers everyone who resides in Norway. At around the same time, Norway started recording detailed data on its population in national population-wide registers. These high-quality individual-level data make it possible to 
Postprint version

prospectively investigate the relationships between retirement and mortality in a population-wide sample with an observation window spanning several decades.

\section{DATA}

We primarily rely on high quality register data on age, migrations, immigrant background, and pension uptake from Norwegian administrative registers. However, the register data from the 1960s and early 1970s are somewhat limited in scope. Importantly, information on occupation and education were not recorded in annually updated registers. For information on occupations and education, we have therefore linked the register data to information from the 1960 and 1970 census. This does, however, introduce some practical difficulties; people who died before the 1970 census have missing data on education and occupation from this census.

For occupations, $34.7 \%$ of the men had missing information from the 1970 census, in part due to deaths before 1970. In cases where information was not available in the 1970 census, we used occupations from the 1960 census where these were available. $13.2 \%$ had missing information on occupations in the 1960 census, and by combining these sources, the total number of missing cases fell to $8.2 \%$. People may have changed occupations between 1960 and 1970, but this combination enables us to run subgroup analyses by occupational groups. Among women in the same cohorts, $63 \%$ had no information on occupation in either census, suggesting that they were not employed and thus not at risk for retirement. This is the reason why we have opted not to include women in our analyses.

For data on educational attainment, the categories were coded very differently in the two censuses (Vassenden 1987). It is thus difficult to combine educational data from the two censuses. Because the missing education from the 170 census captures deaths occurring before 1970, and because such deaths are more common in the older cohorts, including this as a covariate "controls away" mortality in the older cohorts that became eligible for retirement later. This produces an artefactual effect of retirement eligibility on mortality in our difference-in-differences (DiD) models (not shown). However, it has no substantive bearing on the results from our instrumental variable (IV) analyses (supplementary material, S1), since these condition on being alive at age 70 (i.e. after the census). To 
Postprint version

avoid these issues, we have opted to base our subgroup analyses by educational level and our main DiD models on information on education taken from the 1960 census. Marital status is only recorded from 1975, making it impossible to include this information in our analysis. Similar data availability issues pertain to a number of other relevant control variables. However, since we utilize presumably exogenous variation in retirement eligibility related to the 1973 reform to estimate the effects, differences between individuals may only affect our results if this variation correlates with the implementation of the reform.

The data we use for our main analyses covers the entire male Norwegian population with a valid ID number that was born between 1902 and 1906 and has been alive and resident at some point after turning 65. Individuals were excluded if they were neither resident, dead or emigrated $(\mathrm{N}=659)$, had non-matching death years or months in the population register files $(\mathrm{N}=21)$, or had missing times of both death and emigration $(\mathrm{N}=1)$. The final dataset contains information on 101803 individuals from the 1902-1906 cohorts ( $99.34 \%$ of the original male sample). The retirement benefit registers were introduced in 1967, so data on pension benefit uptake is only available from this year onwards. Data quality on deaths is also less certain before 1967. To present comparable descriptive statistics on pension benefit uptake and ensure high-quality data on deaths, we therefore condition on being alive at age 65, which corresponds to the year 1967 for the oldest cohort. This reduces the sample to 88273 individuals. In checks for parallel trends and when running some robustness checks, we also include cohorts born in 1901 and between 1907 and 1910.

Immigrant background is coded in three categories. Educational level groups from the 1970 and 1960 censuses are each collapsed into four groups, in addition to a missing category, while the occupational groups were coded into 10 broad groups and a missing category, based on the 1980 occupational group standard (Vassenden 1987). The categorizations are provided in Table 2. Information on pension benefit recipiency was available for each calendar year. We coded one variable containing information on the first year of recipiency for each pension type (old age pensions, disability pensions and all other pension types combined), as well as one variable indicating the first year each individual 
Postprint version

received any type of pension. Old-age retirement eligibility age is given by the reform and was calculated in discrete months.

\section{IDENTIFICATION AND METHODS}

\section{THE PENSION REFORM}

On the 1st of January 1973, the minimum old-age retirement age in the national insurance scheme was lowered from 70 to 67 years (Amendment to the law on social insurance 1972). As a natural experiment, this reform has some appealing features. It is a rather simple reform, as the change happened at a single point in time, so that eligibility is easy to identify. The important eligibility criterion is age, and the eligibility age varies with birth cohort. People could thus not self-select into eligibility. The reform further allows for a long observation window, facilitating the estimation of long-term effects. It also affected the majority of the working population, facilitating generalization across groups (though not necessarily across time). The age groups affected by the reform are also relevant today, as several recent pension reforms have aimed to postpone retirement up to and beyond age 70. Additionally, the reform affected people in their late 60s in the early 1970s. Baseline mortality was higher in this age group in this period than in periods and age groups affected by later reforms. This should make it easier to identify an effect. The higher baseline mortality also means that the 1973 reform serves as a critical case (Flyvbjerg 2006); if an effect of retirement on mortality cannot be found when studying the 1973 reform, it is theoretically unlikely that one can be found by studying later reforms.

The 1973 reform was introduced together with an incentive to postpone retirement that increased the pension benefits for people who retired later (NAV 2011). However, this benefit only worked as an incentive to postpone retirement up to age 70 (the pre-reform limit), and our data suggests that the proportion who retired at or after age 70 also dropped following the reform (not shown). Thus, while it is possible that this reform element induced some defiance, which would bias our IV estimates (Angrist and Pischke 2008:156-7; 2014:112-5; Borgen 2013), we believe that this is unlikely to be a major concern. Some employees in government offices and institutions already had lower statutory 
Postprint version

retirement ages at the time of the reform (Committee on retirement age 1971), but these individuals have proved difficult to identify in our data. This may bias our estimates of the mortality effect of the reform slightly towards zero. Finally, we do not know if this reform primarily induced voluntary or involuntary retirement, making it impossible to assess whether the results reflect the (possibly harmful) effects of involuntary retirement or the (possibly beneficial) effects of voluntary retirement.

\section{THE REFORM EFFECT ON PENSION UPTAKE}

The 1973 reform meant that the 1906 birth cohort could retire at a three years younger age than the 1902 cohort, and that each successive monthly birth cohort born between 1903 and 1905 was allowed to retire at a one-month younger age than the previous cohort (Figure 1). We define retirement as the uptake of pension benefits. There was an option to take partial pension and continue working, but only $3.7 \%$ of men received such income-related pension reductions at age 67 in 1976 (NOU 1978: 12:118119). This indicates that for the vast majority of retirees, benefit uptake meant full retirement from work. Figure 2 plots the mean age of first claiming retirement benefits for the cohorts 1901-1910. Since the claiming of benefits is measured only annually, birth month variation in mean retirement age is not visible in these data, and the effect artificially appears to be shifted by half a year. Comparing Figures 1 and 2, the marked effect of the reform on old-age retirement is clearly visible. Between the 1902 and the 1906 cohorts, the average old age retirement age fell by more than two years. There is a noticeable downward trend in retirement age for all pension types over and above the apparent reform effect, which may be an issue. We attempt to control for this by including a linear trend as a robustness check.

FIGURE 1 HERE

FIGURE 2 HERE

\section{INSTRUMENTAL VARIABLES}

To estimate the long-term effect of retirement age on mortality, we use an IV estimator. We treat retirement eligibility age as an instrument for actual retirement age, including all pension types. 
Postprint version

Variation in retirement eligibility age stems from the 1973 reform, which appears to have had a major effect on actual retirement age. The outcome is a set of dichotomous variables indicating whether or not a person died before a given age. This allows us to estimate the added probability of dying before each age from postponing retirement by one year. The effect estimated is the local average treatment effect for the compliers, i.e. those who were induced to retire earlier by the reform.

Every individual in our sample has an eligibility age. However, people in the early cohorts who became eligible for retirement later are more likely to die before they get the chance to retire. People who die before they receive retirement benefits do not have an actual retirement age. Due to listwise deletions of people without a retirement age, including everyone in the sample would introduce the endogenous condition that people do not die before retirement (cf. Elwert and Winship 2014). Such a condition would artificially reduce mortality in the cohorts that were allowed to retire later and bias our results. Therefore, we condition on being alive at age 70 in our IV models. This condition is endogemous if retirement affects mortality before age 70, but our DiD estimates (below) indicate that this is not the case. Our IV estimator can be expressed as

$$
\begin{aligned}
& X_{i}=\alpha_{1}+\rho Z_{i}+\beta_{1} C_{i}+\varepsilon_{1 i} \\
& Y_{i}=\alpha_{2}+\gamma \hat{X}_{i}+\beta_{2} C_{i}+\varepsilon_{2 i}
\end{aligned}
$$

where $X$ is retirement age measured in discrete years, $Y$ is the probability of being dead at a given age, the $\alpha$ 's are constant terms, the $\varepsilon$ 's are error terms, $Z$ is retirement eligibility age measured in years with months as decimals, the $\rho$ 's, $\beta$ 's and $\gamma$ 's are regression coefficients, and $\boldsymbol{C}$ is a set of control variables (Angrist and Pischke, 2014:98-146).

Since eligibility age is directly related to birth cohort, the validity of the instrument could be questioned if there is a link between birth cohort and mortality, irrespective of retirement behavior (Angrist and Pischke 2014:98-146). Such paths could include for instance systematic educational differences or differences in childhood nutrition or health between monthly birth cohorts that correlate with our instrument and violate the exclusion restriction. 
Postprint version

While we cannot empirically test the validity of our instrument, we attempt to investigate potential sources of bias in several ways. First, we provide a check for balance on some potential confounders. Second, the discrete time hazard model described below is far less sensitive to cohort differences in unobserved characteristics than the IV estimator, and similar results should provide some confidence that our IV results are not strongly biased by unobserved cohort differences. Third, we run robustness checks on both the main IV model and our DiD model.

\section{DISCRETE TIME HAZARD DIFFERENCE-IN-DIFFERENCES}

To estimate the short-term effect of retirement eligibility on mortality, we employ a discrete time hazard difference-in-differences (DiD) model with death at age $a$ as the outcome. We treat age in months as our time dimension and assume that the age specific mortality of the different monthly birth cohorts would be parallel in absence of the pension reform. The treatment is retirement eligibility at age $a$. Retirement eligibility varies with age and cohort due to the 1973 reform, and this variation is assumed to be exogenous. Our dichotomous treatment indicator takes the value one if the individual is eligible for old-age retirement that whole month, otherwise zero. The 1902 cohorts became eligible at age 70, the 1906 cohorts became eligible at age 67, and all other monthly birth cohorts became eligible at an age in between, as shown in Figure 1. Thus, the monthly birth cohorts born in 1906 form our treatment groups from age 67 onwards, the 1902 cohorts form our control groups, while all monthly birth cohorts born in the years 1903 to 1905 one by one move from the control group into the treatment group as they reach their monthly birth cohort's retirement eligibility age. All individuals are observed from age 65 or the first month after they immigrated, to whatever occurs first of death, emigration or right-censoring at age 70 (after which there is no variation in retirement eligibility). Dummies for monthly birth cohort and for age in months net out cohort differentials in mortality that are constant over age as well as age differentials in mortality within each cohort. We present the results as average marginal effects, calculated from our model of the hazard rate of death, which can be written as:

$$
H_{i c a}=\exp \left(\beta_{1} \boldsymbol{A}_{i}+\beta_{2} \boldsymbol{C}_{i}+\beta_{3} E_{i c a}+\beta_{4} \boldsymbol{X}_{i}+e_{i c a}\right)
$$


Postprint version

where $A$ is a set of dummies for age in months (measured as a twelfth of a year) in the range $780 \leq A \leq$ $840, C$ is a set of dummies for monthly birth cohorts, and $E$ is a dummy denoting whether each individual is eligible for retirement at a given age $a$. $X$ denotes a set of observed characteristics that are constant over time for each individual, and $e$ is our error term (see Hernæs et al. 2013 for a similar identification strategy using triple differences).

In this setup, only differences between cohorts that correlate with the implementation of the reform may affect our results. This means that systematic differences between cohorts (such as health differences) may only bias our estimates if they take the form of an interaction of monthly birth cohort and age. Such effects would violate the parallel trends assumption.

As age and cohort perfectly predict calendar years, this variable cannot be included as a control. Hence, the setup is also sensitive to calendar year effects that affect mortality in all the cohorts simultaneously. To overcome such issues, a triple differences estimator would be preferable, but we have not been able to identify a group unaffected by the reform that may be used as a control group for such an analysis.

The model does not condition on actual retirement and thus provides an intention to treat estimate. Ideally, we would have applied an instrumental variables approach to our panel data and thus conditioned on retirement. However, this would introduce an endogenous condition, since people who die before they retire would then not have a retirement age and would be omitted from the analysis. Since the probability of dying before retirement is likely affected by retirement eligibility age, such an approach would provide biased results.

\section{DESCRIPTIVE STATISTICS AND CHECK FOR BALANCE}

The descriptive statistics in Table 2 are shown conditional on being alive at age 65 . They show that there are few immigrants in the sample, and that the majority only has lower secondary education (1970 census) or no general education (1960 census) and worked in manual occupations. Further, the vast majority received some kind of pension benefit, and the majority of those who did, received old age pensions. Many of those who received old age pensions also received some other type of pension 
Postprint version

first, in most cases a disability pension. Relatively few people died or emigrated without having received any kind of pension benefit, and attrition due to emigration is minimal. The mean retirement age is lower for all pensioners than for those who exclusively received old age pensions. The mean death age is close to the actual remaining life expectancy at age 65 in this period (Statistics Norway n.d.). Retirement age is strongly related to birth cohort (to a large part due to the reform), but mortality is not. Further, we see a clear social gradient in both retirement age and mortality, as men with higher education and in white-collar occupations generally both retire later and live longer. An interesting question is thus whether these systematic differences translate into heterogeneity of the effects of retirement on mortality. Finally, it is worth noting the very low mean death age for men with missing educational level from the 1970 census. This is driven by people dying before the census was conducted, and discussed further below.

\section{TABLE 2 HERE}

Table 3 shows two separate regression models for the correlation between a set of potential confounders, and retirement age and retirement eligibility age (our instrument), respectively. Our identification strategy is not perfect. There are a few occupations that are correlated with an earlier retirement eligibility age, indicating that a greater proportion was employed in these occupations in the later cohorts. However, except for military jobs (which accounts for $0.22 \%$ of the total sample), the coefficients are very small when compared to the corresponding coefficients for retirement age. Also, the proportion of immigrants is weakly correlated with our instrument. Since there is apparently some imbalance between the cohorts that are the basis for our instrument, there is some reason for concern that our identification strategy may be invalid. Therefore, it is important to interpret the results with some caution. However, our DiD model does account for time-invariant differences between cohorts, so that compatible results from the IV and DiD models should provide some confidence that timeinvariant cohort differences do not strongly bias our results.

\section{TABLE 3 HERE}


Postprint version

Figure 3 plots the proportions that are dead at ages between 66 and 70 for each monthly birth cohort of men born between 1901 and 1910, conditional on being alive at age 65. There is apparently not much systematic variation in mortality between cohorts. The exception is the cohorts born in 1909 and 1910, where we see a small drop in mortality at higher ages. The cohorts under study (1902-1906) appear to have comparable mortality both before and after some of them become eligible for retirement. Hence, there appears to be no visibly discernible effect of the pension reform on mortality.

\section{FIGURE 3 HERE}

\section{RESULTS}

\section{LONG-TERM EFFECTS OF RETIREMENT AGE}

Table 4 shows separate OLS and IV models for the effect of retirement age on the probability of dying before age 80 , conditional on being alive at age 70 . The OLS estimate is much larger than the IV estimate and has the opposite sign, suggesting that the OLS estimate is strongly biased. The first stage in the IV model is strong. The F-statistic is much larger than the conventional minimum of 10.

Becoming eligible for retirement one year later is associated with retiring approximately three quarters of a year later. The second stage IV estimate reveals that retiring one year later apparently reduces the probability of dying before age 80 by an insignificant 0.13 percentage points among men $(p=0.547)$.

\section{TABLE 4 HERE}

Age 80 is an arbitrarily chosen age of measurement. The effect may be larger or smaller in the shorter or longer term. To test this, we have estimated one IV model identical to the one in Table 4 for each age between 71 and 100 years. First stage regressions are identical to those in Table 4. Results from the second-stage regressions are plotted in Figure 4 and give the impression that postponed retirement causes a minor, short-term reduction in mortality among men. However, the effects are small enough to be both negligible and possibly driven by random fluctuations, life expectancy trends, or endogenous cohort differences in the probability of dying before retirement after age 70 , which results in listwise deletion of observations. 
Postprint version

To assess whether retirement may have a different effect on people with different occupations and educational levels, we have conducted separate IV analyses for different occupational and educational groups (using information on educational level from the 1960 census). As shown in Table 5, these analyses show small effect estimates that vary around zero. None of the estimates are significantly different from zero at the 0.05 level. In other words, we find no evidence to support the notion that retirement has a more positive effect on the mortality of people in blue-collar occupations or people with low education. .

FIGURE 4 HERE

TABLE 5 HERE

\section{SHORT-TERM EFFECTS OF RETIREMENT ELIGIBILITY}

The main results from the DiD models are provided in Table 6. Being eligible for retirement does not appear to substantially affect mortality among men in the short run. Being eligible for retirement in the age span 67-70 reduces the probability of dying by 0.01 percentage points in all models.

\section{TABLE 6 HERE}

To study the short-term temporal profile of the effect of retirement eligibility, we also estimate a similar model to the one presented in equation 4, with controls as in Model 5 of Table 6, but we replace our dichotomous treatment indicator for a set of dummies indicating the number of months that have passed since each individual became eligible for retirement. The results are shown as average marginal effects in Figure 5. These estimates show no systematic time variation in the effect of retirement eligibility, and thus no "honeymoon phase" or "disenchantment phase".

\section{FIGURE 5 HERE}

\section{ROBUSTNESS CHECKS}

The IV results may be biased by systematic differences between birth cohorts. We have run the IV model presented in Table 4 with a linear cohort trend (while including the 1907 cohort to capture the nonlinearity in the relationship between cohort and retirement age). This increases the coefficient size 
Postprint version

to 0.0079 , but does not affect our main conclusions, as the results remain statistically insignificant $(\mathrm{p}=$ 0.560). Estimating reduced form effects of eligibility age on mortality before ages 71-100 yields results similar to the IV estimates provided in Figure 4, indicating that there is little difference between the reduced form effect and the treatment effect for the compliers, as should be expected if there is no effect of retirement age on mortality (supplementary material, S2).

To assess the sensitivity of our IV models to the condition that individuals should be alive at age 70, we have re-estimated the main model multiple times, conditioning on being alive at ages 67 to 72 . Conditioning on being alive at younger ages introduces a bias in the expected direction due to listwise deletion of people who die before they retire. Conditioning on being alive at older ages increases our effect estimate a little, but does not alter our main conclusions (supplementary material, S3). We have also estimated our main IV model conditioning on being alive at age 67, with controls for each yearly birth cohort's probability of surviving from age 66 to their mean retirement age (calculated from the Human Mortality Database, and with controls for each monthly birth cohort's probability of surviving until retirement (calculated from our data), respectively. None of these estimates (supplementary material, S4) led us to doubt our main conclusions.

We have also run a placebo regression for our hazard models where we sampled the cohorts born in the years 1906 through 1910. All of these became eligible for old age pensions at age 67, but in this robustness check we pretend that the reform occurred in 1977, so that the cohorts received their placebo eligibility between ages 67 (1910) and 70 (1906). This should provide a benchmark to which we can compare our hazard models. The result shows no effect of the placebo eligibility variable, indicating that there are no strong cohort-related trends in life expectancy that were suppressed by the reform (supplementary material, S5).

\section{DISCUSSION}

As evident from the theory discussion above, the debate about the potentially harmful effects of retirement have been going on for several decades. An increasing number of studies have recently addressed these questions by studying natural experiments, but the results have so far been 
Postprint version

inconsistent. The main contribution of this study lies in investigating the potential differences in effects of retirement for different occupational and educational groups, and examining the effects of a pension reform that affected a group with relatively high baseline mortality. As we may expect major life changes to have a greater impact on the mortality of older people with higher mortality, we may expect that studying a reform that affected a relatively old group (67-70) in a period with shorter life expectancies (the 1970s) should provide valuable information on the potential upper bound of mortality effects of retirement in general.

The results from our IV analyses do not, however, indicate any lasting effects of retirement age on mortality among men. This is also the case for our $\mathrm{DiD}$ model, which shows no effect of retirement eligibility on mortality. In separate IV analyses for different occupational and educational groups we find no systematic differences between the groups, and the effect estimates are generally small and statistically insignificant, despite systematic group differences in both retirement age and mortality. Insofar as these groups reflect socioeconomic strata, our results do not show clear socioeconomic differences in the effect of retirement on male mortality. Our main conclusions are thus in line with the results from Coe and Lindeboom (2008), Hagen (2017), Lalive and Staubi (2015) and Hernæs et al. (2013); we find no effect of retirement on mortality.

The fact that we could not identify a substantive effect in our high-mortality sample suggests that it is unlikely that retirement affects mortality in populations of younger and presumably healthier workers. It also suggests that the theoretical literature may have overstated the impact of retirement on mortality, as suggested by Ekerdt (1987). Further, our results indicate that retiring from different types of occupations does not have a differential effect on mortality.

However, our study has several limitations. First, the fact that we do not study women is an important shortcoming. Although the omittance of women was necessary due to the low labor force participation of elderly women in the 1970s, subsequent studies should attempt to include both women and men. Second, our approach does not account for potential biases from events that may have affected all cohorts simultaneously or interactions between cohort and age. Accounting for such effects would have required us to apply a triple differences estimator, but, as discussed above, we have not been able 
Postprint version

to do so. Third, we do not know if retirement was voluntary or not, and as such, we could not assess whether voluntary retirement affects mortality differently than involuntary retirement.

Finally, while studying the 1973 reform has some advantages, the relevance of this reform to presentday elderly workers is limited by the fact that today's societies are quite different from that of 1970's Norway. For instance, the relatively generous pension system, the regulated labor market, and the affordable and expansive public healthcare system in Norway could mean that any effect of retirement on health and mortality could be attenuated in Norway compared to other countries. However, improvements in working conditions and healthcare, as well as welfare expansions and increases in life expectancy that have taken place since the 1970s would suggest that an effect of retirement on mortality would be smaller in present day. To address these and other questions, studies of more recently retired people in other national contexts would be most welcome.

\section{CONCLUSIONS}

Several theories predict that retirement should affect mortality, that there should be health benefits from retiring from strenuous jobs, or that working may have some protective effect on health and longevity. We argue that given the inconsistent findings in previous research, studying the effects of retirement on mortality in a sample of relatively old individuals where baseline mortality is high provides a critical case for investigating whether such effects exist. Studying the effects of a reduction in retirement eligibility age that occurred in Norway in 1973 and affected people in the ages 67 to 70 , we find no substantive effect of retirement or retirement eligibility on mortality among men in the long or short run. Further, we find no evidence suggesting differences in the mortality effects of retirement for men in different occupational or educational groups. 
Postprint version

\section{REFERENCES}

Amendment to the law on social insurance (1972). Law of June 16th 1972 number 60 on amendments of the law of June 17th 1966 number 12 on social insurance (folketrygd) (1972).

Angrist, J. D., \& Pischke, J.-S. (2008). Mostly harmless econometrics: An empiricist's companion. Princeton and Oxford: Princeton university press.

Angrist, J. D., \& Pischke, J.-S. (2014). Mastering 'metrics: The path from cause to effect. Princeton and Oxford: Princeton University Press.

Atchley, R. C. (1976). The Sociology of Retirement. Cambridge, Massachusetts: Schenkman Publishing Company, Inc.

Atchley, R. C. (1989). A continuity theory of normal aging. The Gerontologist, 29, 183-190.

Bamia, C., Trichopoulou, A., \& Trichopoulos, D. (2008). Age at Retirement and Mortality in a General Population Sample: The Greek EPIC Study. American Journal of Epidemiology, 167, 561-569.

Bingley, P., \& Pedersen, P. J. (2011). Does early retirement keep you healthy and extend your life? Preliminary version 2.1. The Danish National Center for Social Research, Copenhagen School of Economics and Management, Aarhus University.

Bloemen, H., Hochguertel, S. \& Zweerink, J. (2017). The causal effect of retirement on mortality: Evidence from targeted incentives to retire early. Health Economics. 2017, 1-15.

Blekesaune M. \& Veenstra M. (2010) Helsesvikt og pensjoneringsatferd. Tidsskrift for velferdsforskning 13, 8394.

Bonsang, E., Adam, S., \& Perelman, S. (2012). Does retirement affect cognitive functioning? Journal of Health Economics, 31, 490-501.

Borgen, N. T. (2013). Instrumentvariabler - en introduksjon for samfunnsforskere. Sosiologi i dag, 43, 39-64. Brathaug, A. L., \& Skoglund, T. (2012). Historisk nasjonalregnskap. Langvarig vekst i norsk фkonomi. Article. Statistics Norway. https://www.ssb.no/nasjonalregnskap-og-konjunkturer/artikler-og-publikasjoner/langvarigvekst-i-norsk-okonomi Accessed 11 January 2017.

Brockmann, H., Müller, R., \& Helmert, U. (2009). Time to retire-Time to die? A prospective cohort study of the effects of early retirement on long-term survival. Social science \& medicine, 69, 160-164.

Carlsson, S., Andersson, T., Michaëlsson, K., Vågerö, D., \& Ahlbom, A. (2012). Late retirement is not associated with increased mortality, results based on all Swedish retirements 1991-2007. European Journal of Epidemiology, 27, 483-486. 


\section{Postprint version}

Coe, N. B., \& Lindeboom, M. (2008). Does retirement kill you? Evidence from early retirement windows. IZA Discussion paper, No. 3817.

Cumming, E., \& Henry, W. E. (1961). Growing old. The process of disengagement. New York: Basic Books.

Daatland, S. O., \& Solem, P. E. (2000). Aldring og samfunn. En innføring i sosialgerontologi. Bergen: Fagbokforlaget.

Eibich, P. (2015). Understanding the effect of retirement on health: mechanisms and heterogeneity. Journal of health economics, 43, 1-12.

Eika, T. (2008). Det svinger i norsk økonomi. Samfunnsspeilet, 5-6/2008, 98-111

Ekerdt, D. J. (1987). Why the notion persists that retirement harms health. The Gerontologist, 27, 454-457.

Ekerdt, D. J., Bossé, R., \& Levkoff, S. (1985). An empirical test for phases of retirement: Findings from the Normative Aging Study. Journal of Gerontology, 40, 95-101.

Elwert, F., \& Winship, C. (2014). Endogenous Selection Bias: The Problem of Conditioning on a Collider Variable. Annual review of sociology, 40, 31-53.

Fitzpatrick, M. D., \& Moore, T. J. (2018). The mortality effects of retirement: Evidence from Social Security eligibility at age 62. Journal of Public Economics, 157, 121-137.

Flyvbjerg, B. (2006). Five misunderstandings about case-study research. Qualitative inquiry, 12, 219-245.

Grøtting, M. W. \& Lillebø, O. S (2017). Health Effects of Retirement. Evidence from Norwegian Survey and Register Data. Working Papers In Economics No. 2/17 Department of Economics, University Of Bergen.

Hagen, J. (2018). The effects of increasing the normal retirement age on health care utilization and mortality. Journal of Population Economics, 31, 193-234.

Hallberg, D., Johansson, P., \& Josephson, M. (2015). Is an early retirement offer good for your health? Quasiexperimental evidence from the army. Journal of Health Economics, 44, 274-285.

Havighurst, R. J. (2009). Successful aging. In R. H. Williams, C. Tibbitts \& W. Donohue (Eds.), Processes of aging: Social and psychological perspectives (pp. 299-320). New Brunswick, NJ: Transaction Publishers. (Original work published 1963)

Haynes, S. G., McMichael, A. J., \& Tyroler, H. A. (1978). Survival After Early and Normal Retirement. Journal of Gerontology, 33, 269-278.

Hernæs, E., Markussen, S., Piggott, J., \& Vestad, O. L. (2013). Does retirement age impact mortality? Journal of Health Economics, 32, 586-598. 
Postprint version

Hochschild, A. R. (1975). Disengagement Theory: A Critique and Proposal. American Sociological Review, 40, $553-569$.

Kim, J. E., \& Moen, P. (2002). Retirement Transitions, Gender, and Psychological Well-Being: A Life-Course, Ecological Model. The Journals of Gerontology Series B: Psychological Sciences and Social Sciences, 57, 212-222.

Kjølsrød, L. (2011). Small Country, Large Welfare State. In O. Molven \& J. Ferkis (Eds.), Healthcare, Welfare and Law. Health legislation as a mirror of the Norwegian welfare state (pp. 13-27). Oslo: Gyldendal Akademisk.

Kuhn, A., Wuellrich, J.-P., \& Zweimüller, J. (2010). Fatal attraction? Access to early retirement and mortality. IZA discussion paper No. 5160

Kühntopf, S., \& Tivig, T. (2012). Early retirement and mortality in Germany. European Journal of Epidemiology, 27, 85-89.Lalive, R., Staubli, S. (2015). How Does Raising Women's Full Retirement Age Affect Labor Supply, Income, and Mortality? Evidence from Switzerland. NBER Retirement Research Center Paper No. NB 14-09

Li, C.-Y., \& Sung, F.-C. (1999). A review of the healthy worker effect in occupational epidemiology. Occupational Medicine, 49, 225-229.

Litwin, H. (2007). Does early retirement lead to longer life? Ageing and Society, 27 (5), 739-754.

Martin, J., \& Doran, A. (1966). Evidence concerning the relationship between health and retirement. The Sociological Review, 14, 329-343.

Mein, G., Martikainen, P., Stansfeld, S. A., Brunner, E. J., Fuhrer, R., \& Marmot, M. G. (2000). Predictors of early retirement in British civil servants. Age and Ageing, 29, 529-536.

Minkler, M. (1981). Research on the health effects of retirement: an uncertain legacy. Journal of Health and Social Behavior, 22, 117-130.

Munch, J. R., \& Svarer, M. (2005). Mortality and socio-economic differences in Denmark: a competing risks proportional hazard model. Economics \& Human Biology, 3, 17-32.

NAV (2011). Rundskriv § 19-19 Ventetillegg, Folketrygdloven.

NOU 1978: 12 (1978). Pensjonsutredningen. Om forbedring av minstepensjonene i folketrygden og forskjellige andre spфrsmål om folketrygdens ytelser. The ministry of social affairs. February 2nd 1978.

Nuttman-Shwartz, O. (2004). Like a high wave: Adjustment to retirement. The Gerontologist, 44, 229-236. OECD. (2013). Pensions at a Glance 2013: OECD and G20 Indicators. OECD Publishing. 
Postprint version

Pensjonsalderkomitéen. (1971). Innstilling fra Pensjonsalderkomitéen. Innstillinger og betenkninger. Oslo: Sosialdepartementet.

Quaade, T., Engholm, G., Johansen, A. M. T., \& Møller, H. (2002). Mortality in relation to early retirement in Denmark: a population-based study. Scandinavian journal of public health, 30, 216-222.

Rice, N. E., Lang, I. A., Henley, W., \& Melzer, D. (2011). Common health predictors of early retirement: findings from the English Longitudinal Study of Ageing. Age and Ageing, 40, 54-61.

Richardson, V., \& Kilty, K. M. (1991). Adjustment to retirement: continuity vs. discontinuity. The International Journal of Aging \& Human Development, 33, 151-169.

Shim, M. J., Gimeno, D., Pruitt, S. L., McLeod, C. B., Foster, M. J., \& Amick, B. C. (2013). A Systematic Review of Retirement as a Risk Factor for Mortality. In N. Hoque, A. M. McGehee \& S. B. Bradshaw (Eds.), Applied Demography and Public Health (pp. 277-309). Dordrecht: Springer Netherlands.

Skirbekk, V., Telle, K., Nymoen, E., \& Brunborg, H. (2010). Retirement and mortality in Norway-Is there a real connection? In T. Salzmann, V. Skirbekk \& M. Weiberg (Eds.), Wirtschaftspolitische herausforderungen des demografischen wandels (pp. 201-222). Wiesbaden: VS Verlag für Sozialwissenschaften.

Solem, P. E. (1987). Mortality during the first five years after reaching retirement age. In L. Levi (Ed.), Society, stress and disease: Vol 5 Aging and old age (pp. 236-248). Oxford: Oxford University Press.

Statistics Norway (n.d.). Table 07902: Life tables, bye sex and age. Table. Statistics Norway. https://www.ssb.no/en/statbank/table/07902/?rxid=c9026d61-5e6c-488b-9092-77210ce6bfed Accessed 9 April 2018.

Syse, A., Veenstra, M., Furunes, T., Mykletun, R. J., \& Solem, P. E. (2015). Changes in Health and Health Behavior Associated With Retirement. Journal of aging and health, 0898264315624906.

The World Bank. (n.d.). GDP per capita (current US\$). Table. The World Bank. http://data.worldbank.org/indicator/NY.GDP.PCAP.CD?year_high_desc=true Accessed 11 January 2017.

Tsai, S. P., Wendt, J. K., Donnelly, R. P., de Jong, G., \& Ahmed, F. S. (2005). Age at retirement and long term survival of an industrial population: prospective cohort study. British Medical Journal, 331.

van den Bogaard, L., Henkens, K., \& Kalmijn, M. (2016). Retirement as a relief? The role of physical job demands and psychological job stress for effects of retirement on self-rated health. European Sociological Review, 32, 295-306.

van der Heide, I., van Rijn, R. M., Robroek, S. J., Burdorf, A., \& Proper, K. I. (2013). Is retirement good for your health? A systematic review of longitudinal studies. BMC Public Health, 13. 


\section{Postprint version}

van Solinge, H., \& Henkens, K. (2008). Adjustment to and satisfaction with retirement: two of a kind? Psychology and aging, 23, 422-434.

Vassenden, K. (1987). Folke- og boligtellingene 1960, 1970 og 1980. Dokumentasjon av de sammenlignbare filene. Rapporter fra Statistisk sentralbyrå 87/2. Oslo/Kongsvinger: Statistics Norway.

Waldron, H. (2001). Links between early retirement and mortality. ORES Working Paper Number 93.

Washington, DC: Social Security Administration, Office of Policy, Office of Research, Evaluation, and Statistics.

Westerlund, H., Kivimäki, M., Singh-Manoux, A., Melchior, M., Ferrie, J. E., Pentti, J., Jokela, M., Leineweber, C., Goldberg, M., Zins, M., \& Vahtera, J. (2009). Self-rated health before and after retirement in France (GAZEL): a cohort study. The Lancet, 374, 1889-1896.

Wu, C., Odden, M. C., Fisher, G. G., \& Stawski, R. S. (2016). Association of retirement age with mortality: a population-based longitudinal study among older adults in the USA. Journal of Epidemiology and Community Health, 70, 917-923. 
Fig. 1 Earliest old-age retirement eligibility by monthly birth cohort.

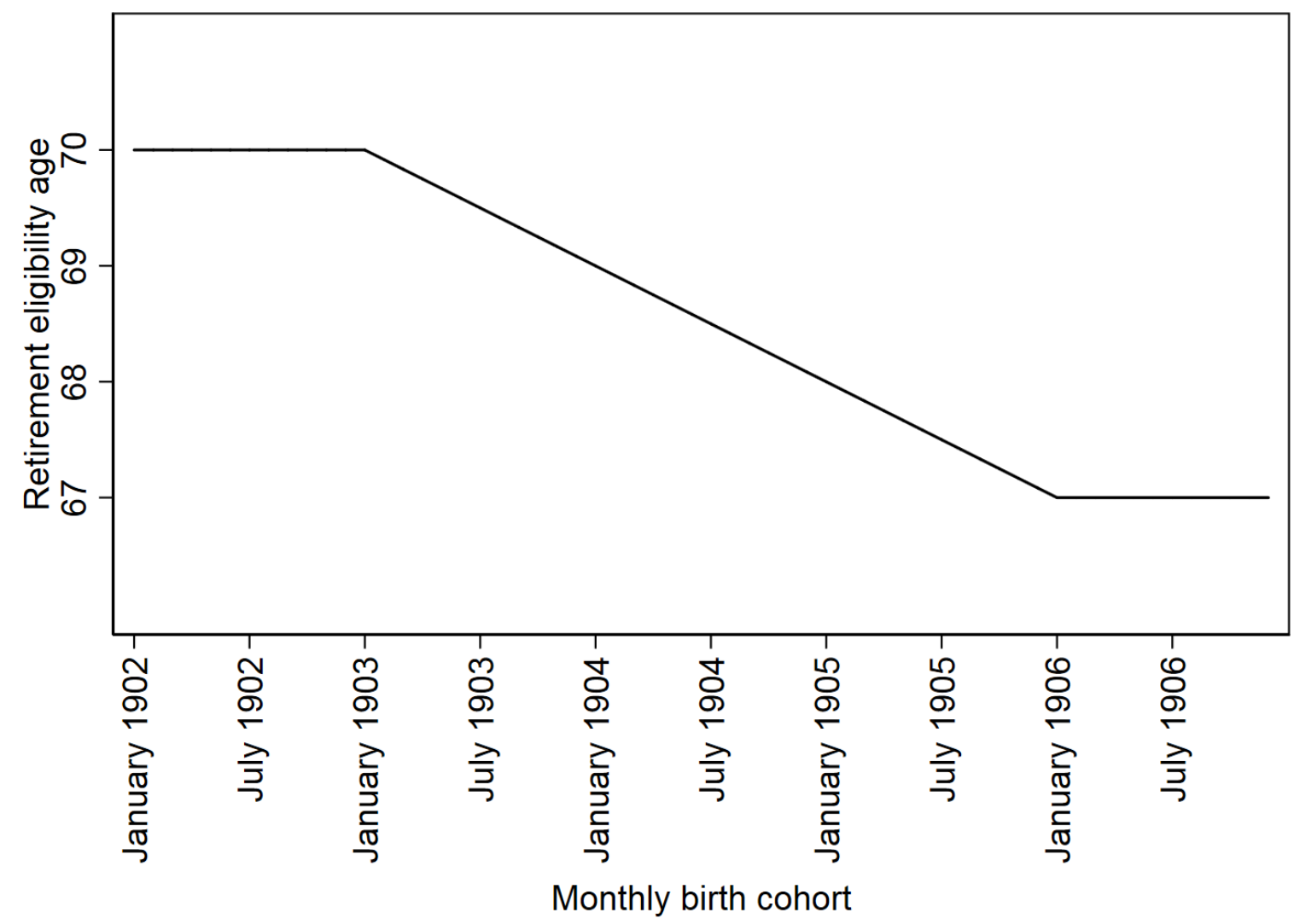


Fig. 2 Mean earliest actual retirement age for people retiring with old age pensions and all pensions combined, by birth cohort.

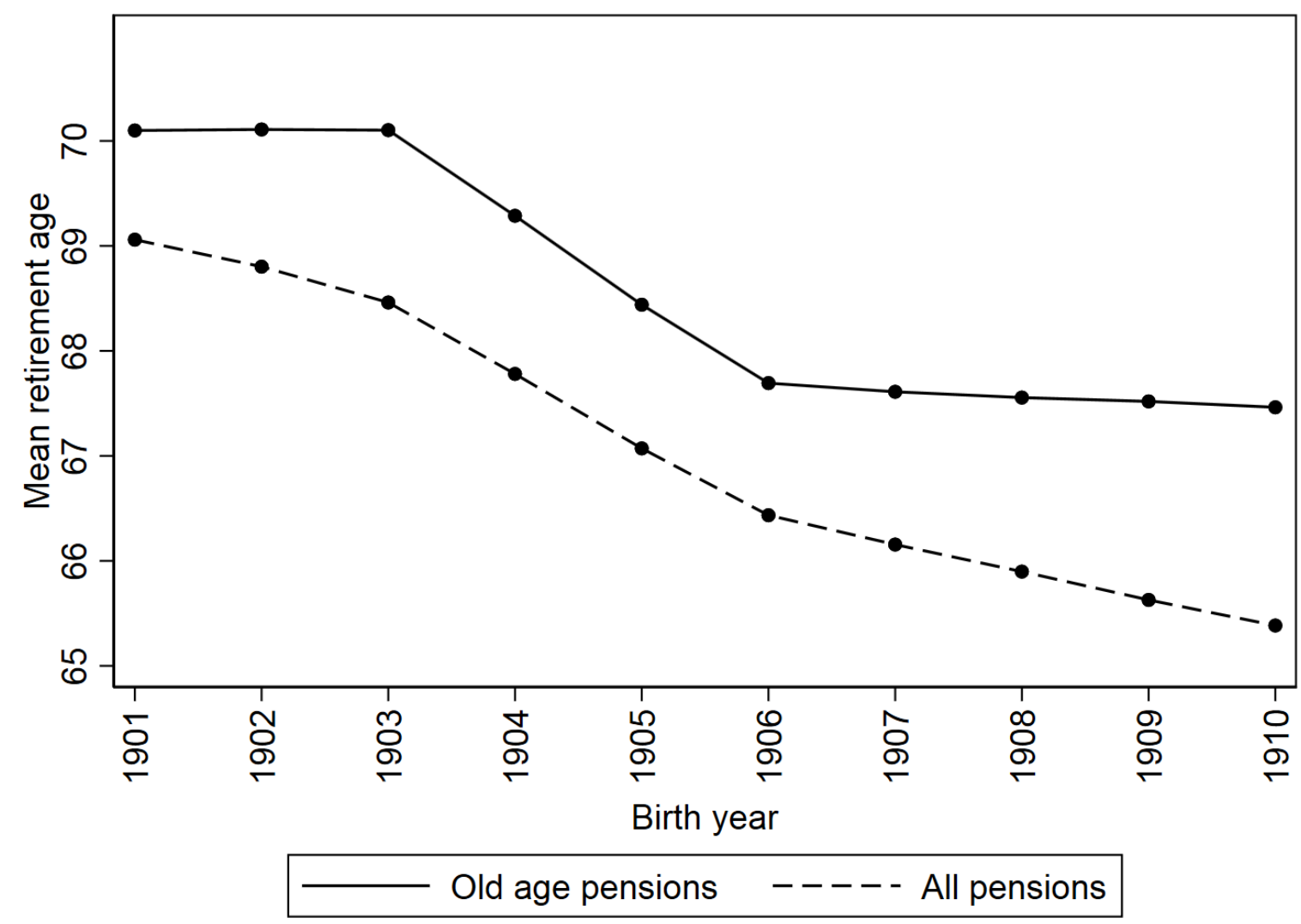


Fig. 3 Proportions who are dead at ages 66, 67, .. 70 by monthly birth cohort, conditional on being alive at age 65

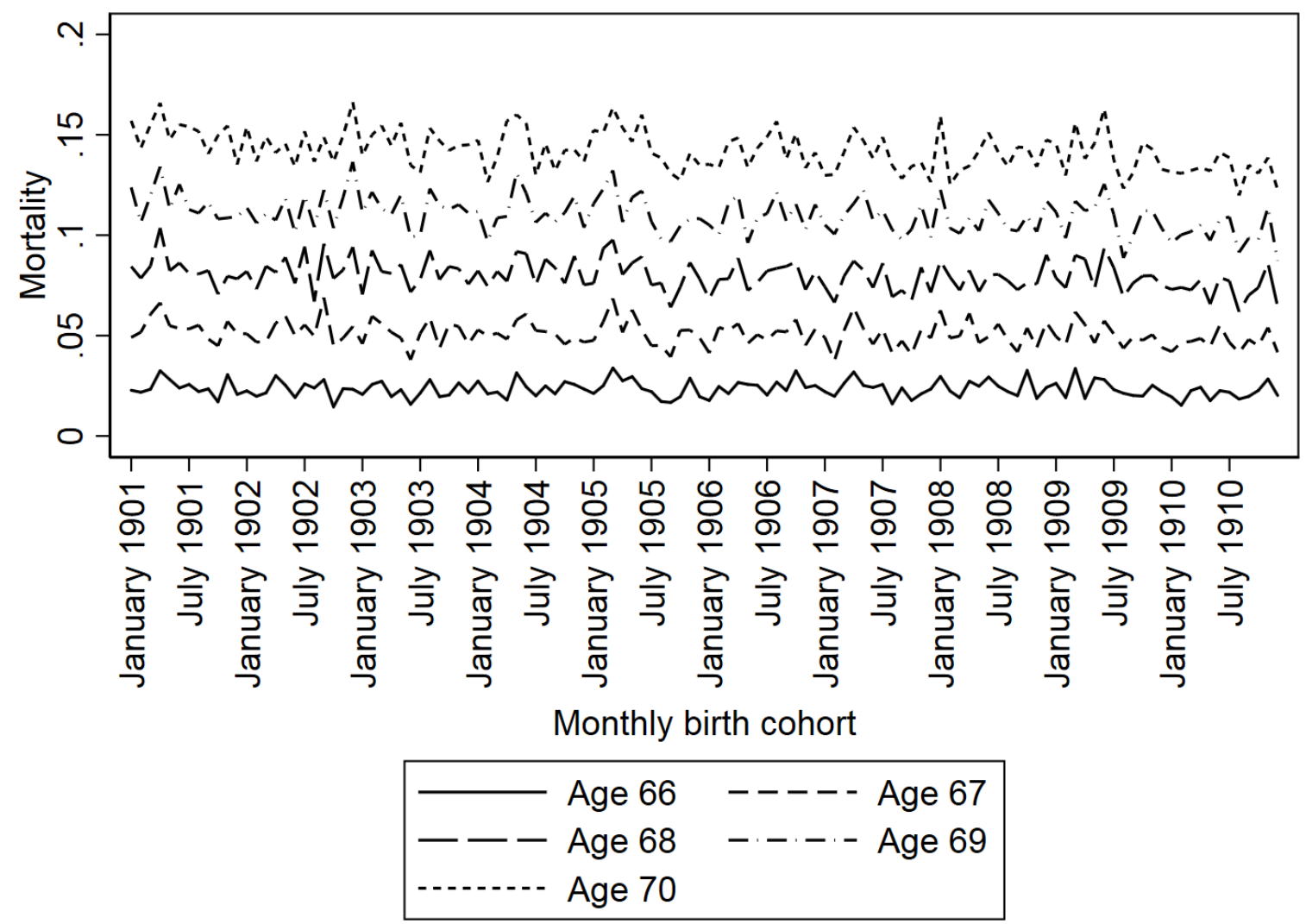


Postprint version

Fig. 4 IV point estimates and $95 \%$ confidence intervals for the effect of retiring one year later on the probability of dying before different ages. Conditional on being alive at age 70.

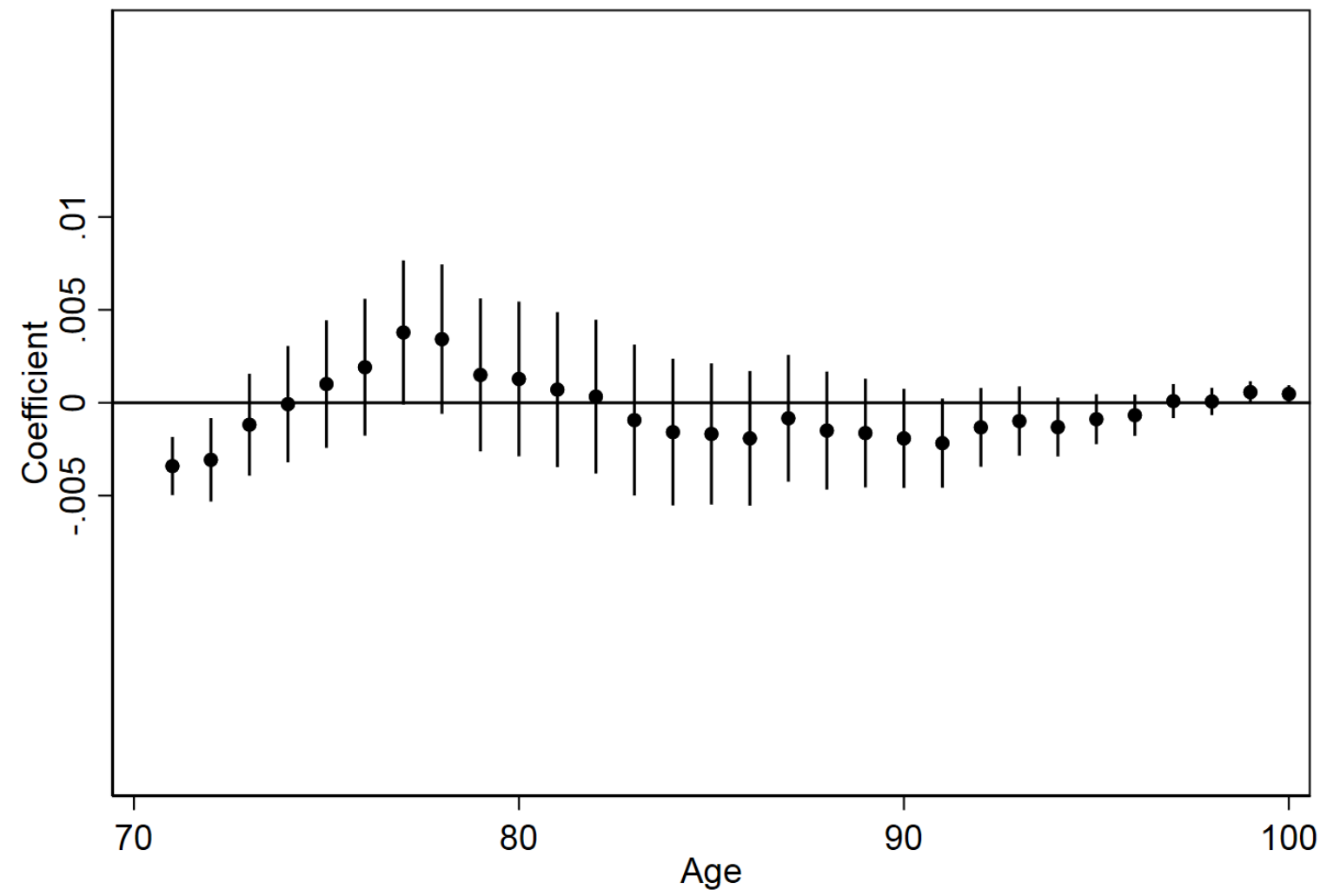

Effect of one year higher retirement age on the probability of dying before ages $71-100$

Note: control variables as in Table 4. 
Postprint version

Fig. 5 Average marginal effects of being eligible for retirement for a given number of months on the probability of death. Estimates from discrete time hazard regressions including duration-specific treatment indicators. Conditional on being alive at age 65.

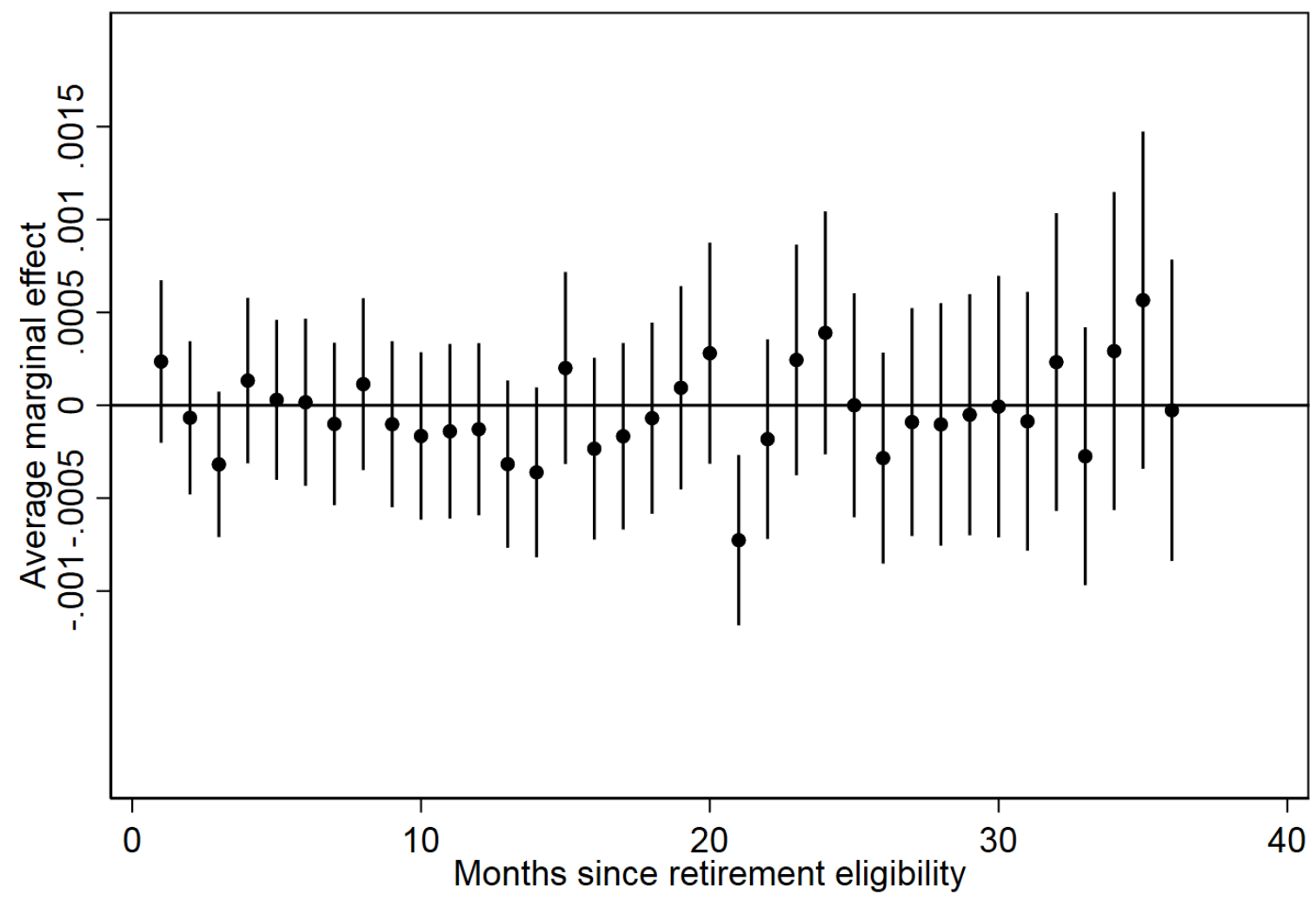

Effect of retirement eligibility on mortality by duration

Note: Controls as in Model 5, Table 6. 
Table 1: Comparison of studies with causally oriented research designs

\begin{tabular}{|c|c|c|c|c|c|c|c|}
\hline Authors & Country & Sex & Sample (treatment group) & Time & Ages affected & Methods & Effect of retirement \\
\hline $\begin{array}{l}\text { Bingley and Pedersen } \\
\text { (2011) }\end{array}$ & Denmark & Men & $\begin{array}{l}\text { Blue collar employees from cohorts 1906- } \\
1921\end{array}$ & 1979 reform & $60-66$ & IV & Reduced mortality \\
\hline Bloemen et al. (2017) & Netherlands & Men & Civil servants aged 53-60 during 2000-2005 & 2005 window & 55 and above & $\begin{array}{l}\text { IV with } \\
\text { individual FE }\end{array}$ & Reduced mortality \\
\hline Hallberg et al. (2015) & Sweden & Men & Military personnel born 1938-1939 & 1992-1997 window & $55-60$ & DiDiD & Reduced mortality \\
\hline $\begin{array}{l}\text { Coe and Lindeboom } \\
\text { (2008) }\end{array}$ & USA & Men & $\begin{array}{l}\text { Health and retirement survey, employees in } \\
\text { cohorts } 1931-1941\end{array}$ & 1992-2004 windows & $50-70$ & IV & No effect \\
\hline Hagen (2017) & Sweden & Women & Local government workers, born 1938-1942 & 2000 reform & $63-65$ & DiD and IV & No effect \\
\hline Hernæs et al. (2013) & Norway & $\begin{array}{l}\text { Women } \\
\text { and men }\end{array}$ & Full cohorts 1928-1938 in AFP firms & 1990 s reforms & $62-67$ & IV and DiDiD & No effect \\
\hline $\begin{array}{l}\text { Lalive and Staubli } \\
(2015)\end{array}$ & Switzerland & Women & $\begin{array}{l}25 \% \text { random sample, cohorts } 1938-1939 \\
1941-1942\end{array}$ & $\begin{array}{l}\text { Reform that came into } \\
\text { effect in } 2001 \text { and } 2005\end{array}$ & $62-63,63-64$ & $\begin{array}{l}\text { Regression } \\
\text { discontinuity }\end{array}$ & No effect \\
\hline $\begin{array}{l}\text { Fitzpatrick and Moore } \\
\text { (2017) }\end{array}$ & USA & $\begin{array}{l}\text { Women } \\
\text { and men }\end{array}$ & People born between 1921 and 1948 & Deaths 1983-2010 & $\begin{array}{l}62 \text { (social security } \\
\text { eligibility) }\end{array}$ & $\begin{array}{l}\text { Regression } \\
\text { discontinuity }\end{array}$ & $\begin{array}{l}\text { Increased mortality } \\
\text { among men }\end{array}$ \\
\hline Kuhn et al. (2010) & Austria & $\begin{array}{l}\text { Women } \\
\text { and men }\end{array}$ & $\begin{array}{l}\text { Blue collar workers in affected regions in } \\
\text { cohorts 1929-1941 (men) and 1934-1941 } \\
\text { (women) }\end{array}$ & 1988-1993 window & $\begin{array}{l}\text { Women } 50-53.5 \text {, } \\
\text { men } 55-58.5\end{array}$ & IV & $\begin{array}{l}\text { Increased mortality } \\
\text { among men }\end{array}$ \\
\hline
\end{tabular}




\section{Postprint version}

Table 2 Descriptive statistics

\begin{tabular}{|c|c|c|c|c|c|}
\hline & & $\begin{array}{l}\text { Mean } \\
\text { ent age } \\
\text { ension } \\
\text { types) }\end{array}$ & SD & $\begin{array}{r}\text { Mean } \\
\text { death age }\end{array}$ & SD \\
\hline Number in 1902 cohort & 17656 & 68.80 & 2.03 & 79.04 & 7.92 \\
\hline Number in 1903 cohort & 17713 & 68.48 & 2.35 & 79.10 & 7.98 \\
\hline Number in 1904 cohort & 17438 & 67.84 & 2.40 & 79.13 & 7.92 \\
\hline Number in 1905 cohort & 17442 & 67.17 & 2.42 & 79.09 & 7.91 \\
\hline Number in 1906 cohort & 18024 & 66.57 & 2.57 & 79.21 & 7.91 \\
\hline Total & 88273 & 67.75 & 2.50 & 79.12 & 7.93 \\
\hline \multicolumn{6}{|l|}{ Percent in different immigrant categories } \\
\hline Norwegian-born with two Norwegian-born parents & 98.02 & 67.74 & 2.49 & 79.12 & 7.93 \\
\hline Immigrants & 1.91 & 68.54 & 3.04 & 78.96 & 8.02 \\
\hline Others & 0.07 & 68.80 & 3.12 & 81.42 & 7.67 \\
\hline \multicolumn{6}{|l|}{ Percent with different educational levels from the 1960 census } \\
\hline No general education or non-response & 63.88 & 67.42 & 2.53 & 78.81 & 7.83 \\
\hline Secondaty school or similar & 9.71 & 68.10 & 2.25 & 80.40 & 8.03 \\
\hline Middle school, vocational school or similar & 17.80 & 68.33 & 2.15 & 79.22 & 8.03 \\
\hline High school ("examen artium") or univerity/college & 5.35 & 69.06 & 1.75 & 80.32 & 8.30 \\
\hline Missing & 3.26 & 68.26 & 3.83 & 78.85 & 7.79 \\
\hline \multicolumn{6}{|l|}{ Percent with different educational levels from the 1970 census } \\
\hline None & 0.49 & 65.59 & 2.97 & 77.68 & 7.14 \\
\hline Lower secondary & 71.24 & 67.54 & 2.50 & 79.47 & 7.56 \\
\hline Upper secondary & 16.54 & 68.38 & 2.15 & 79.84 & 7.74 \\
\hline University/college & 6.19 & 69.09 & 1.65 & 81.24 & 7.98 \\
\hline Missing & 5.53 & 67.03 & 4.05 & 69.33 & 6.94 \\
\hline \multicolumn{6}{|c|}{ Percent in different occupation groups from the 1970 and 1960 census } \\
\hline Technical, scientific, humansitic and artistic work & 6.43 & 68.97 & 1.73 & 80.43 & 8.38 \\
\hline Corporate and organizational management, administration & 4.23 & 68.93 & 1.81 & 79.66 & 8.19 \\
\hline Office and clerical work & 3.73 & 68.78 & 1.81 & 79.17 & 7.94 \\
\hline Trade work and sales & 5.36 & 68.29 & 2.22 & 78.82 & 8.00 \\
\hline Agriculture, forestry and fishing & 25.57 & 67.38 & 2.57 & 80.12 & 7.93 \\
\hline Mining & 0.61 & 67.44 & 2.35 & 78.98 & 7.60 \\
\hline Transport and communications & 7.56 & 67.95 & 2.31 & 78.42 & 7.75 \\
\hline Industry and construction & 33.77 & 67.83 & 2.22 & 78.86 & 7.73 \\
\hline Services & 4.29 & 68.13 & 2.20 & 78.62 & 7.87 \\
\hline Military jobs & 0.22 & 68.46 & 1.99 & 78.60 & 8.35 \\
\hline Missing & 8.23 & 65.88 & 3.50 & 76.75 & 7.70 \\
\hline Number who immigrated between ages 65 and 70 & 80 & & & & \\
\hline Number who immigrated at ages $70+$ & 132 & & & & \\
\hline Number who emigrated between ages 65 and 70 & 3 & & & & \\
\hline Number who emigrated at ages $70+$ & 543 & & & & \\
\hline Number that ever received old age pensions & 76627 & & & & \\
\hline Number that ever received disability pensions & 28795 & & & & \\
\hline Number that ever received other pensions & 394 & & & & \\
\hline Number that ever received any pension & 81654 & & & & \\
\hline Mean retirement age - excluding disability pensioners & 69.14 & & & & \\
\hline Standard deviation & 1.32 & & & & \\
\hline Mean retirement age - including only old age pensioners & 69.16 & & & & \\
\hline Standard deviation & 1.30 & & & & \\
\hline
\end{tabular}


Table 3 OLS regressions for the association between retirement age and a set of potential confounders, and between retirement eligibility age (our instrument) and the same set of potential confounders.

Occupations

Ref: Technical, scientific,

humanistic and artistic work

Corporate and organizational management and administration

Office and clerical work

Trade work and sales

Agriculture, forestry and fishing

Mining

Transport and communications

Industry and construction

Services

Military jobs

Missing

Immigrant category

Ref: Norwegian-born with two

Norwegian-born parents

Immigrants

Others

Educational level (1970 census)

Ref: None

Lower secondary

Upper secondary

University/college

Missing

Constant

$\mathrm{N}$

$\mathrm{P}>\mathrm{F}$

$\mathrm{R}^{2}$
0.1943

$0.1987 * * *$

$-0.1199$

$-0.9494 * * *$

$-0.9048 * * *$

$-0.3784 * * *$

$-0.4972 * * *$

$-0.2509 * * *$

$-0.2586$

$-2.5483 * * *$

0.6897

$1.2074 * * *$

$1.6565 * * *$

$1.9640 * * *$

$5.3191 * * *$

67.2705
$-0.0421$

$-0.0116$

$-0.0696 *$

$-0.0023$

$-0.0922$

$-0.0550$

$-0.0884 * * *$

$-0.0304$

$-0.2037 *$

0.2067

$0.0584 \quad 0.000$

.

$-0.0862 * *$

0.2927

$\begin{array}{ll}0.0784 & 0.000 \\ 0.3624 & 0.057\end{array}$

$\begin{array}{ll}0.0321 & 0.007\end{array}$

$0.1510 \quad 0.053$

Note: $* p<.05 ; * * p<.01 ; * * * p<.001$

Eligibility age

Robust SE P 
Postprint version

Table 4 OLS and IV estimates of the effect of retirement age (in years) on the probability of dying before age 80. Conditional on being alive at age 70

\begin{tabular}{cc} 
OLS & IV \\
\hline Coefficient & Coefficient \\
(Robust SE) & (Robust SE) \\
\hline
\end{tabular}

First stage

Eligibility age (years)

$0.7380 * * *$

(0.0065)

Educational level dummies (1970 census) ${ }^{a}$ yes Immigrant background dummies ${ }^{b}$ yes Occupational group dummies ${ }^{c}$ yes

F-statistic

1390.37

Adjusted $\mathrm{R}^{2}$

0.2455

Second stage

Retirement age (years) $-0.0301 * * * \quad 0.0013$

$(0,0008) \quad(0.0021)$

Educational level dummies (1970 census) ${ }^{a}$ yes yes Immigrant background dummies ${ }^{b}$ Occupational group dummies ${ }^{c}$ $\mathrm{N}$ yes yes

\begin{tabular}{rr} 
yes & yes \\
\hline 74315 & 74315 \\
\hline
\end{tabular}

Note: $* p<.05 ; * * p<.01 ; * * * p<.001$

${ }^{a}$ Educational level in four categories plus missing.

${ }^{b}$ Immigrant background in three categories.

${ }^{c}$ Occupations in 10 groups plus missing. 
Table 5 IV estimates of the effect of retirement age (in years) on the probability of dying before age 80 for men in different occupational and educational groups. Conditional on being alive at age 70

\begin{tabular}{|c|c|c|c|c|c|}
\hline Occupational groups & $\begin{array}{c}\text { Technical, } \\
\text { scientific, } \\
\text { humansitic and } \\
\text { artistic work } \\
\text { Coefficient } \\
\text { (Robust SE) } \\
\end{array}$ & $\begin{array}{c}\text { Corp. and org. } \\
\text { management, } \\
\text { administration } \\
\text { Coefficient } \\
\text { (Robust SE) } \\
\end{array}$ & $\begin{array}{c}\text { Office and } \\
\text { clerical work } \\
\text { Coefficient } \\
\text { (Robust SE) } \\
\end{array}$ & $\begin{array}{l}\text { Trade work } \\
\text { and sales } \\
\text { Coefficient } \\
\text { (Robust SE) } \\
\end{array}$ & $\begin{array}{c}\begin{array}{c}\text { Agriculture, } \\
\text { forestry and } \\
\text { fishing }\end{array} \\
\text { Coefficient } \\
\text { (Robust SE) } \\
\end{array}$ \\
\hline \multicolumn{6}{|l|}{ First stage } \\
\hline Eligibility age (years) & $\begin{array}{rl}0.4839 & * * * \\
(0.0181) & \end{array}$ & $\begin{array}{rl}0.4831 & * * * \\
(0.0243) & \end{array}$ & $\begin{array}{rl}0.5438 & * * * \\
(0.0262) & \end{array}$ & $\begin{array}{rl}0.5471 & * * * \\
(0.0262) & \end{array}$ & $\begin{array}{rl}0.8200 & * * * \\
(0.0138) & \end{array}$ \\
\hline Educational level (1970 census $)^{a}$ & yes & yes & yes & yes & yes \\
\hline Immigrant $^{b}$ & yes & yes & yes & yes & yes \\
\hline F-statistic & 151.89 & 64.25 & 65.30 & 70.68 & 572.33 \\
\hline Adjusted $\mathrm{R}^{2}$ & 0.1628 & 0.1355 & 0.1484 & 0.1127 & 0.1638 \\
\hline \multicolumn{6}{|l|}{ Second stage } \\
\hline Retirement age (years) & $\begin{array}{r}0.0103 \\
(0.0126)\end{array}$ & $\begin{array}{r}0.0180 \\
(0.0158)\end{array}$ & $\begin{array}{r}0.0060 \\
(0.0150)\end{array}$ & $\begin{array}{r}-0.0115 \\
(0.0124)\end{array}$ & $\begin{array}{r}0.0053 \\
(0.0037)\end{array}$ \\
\hline Educational level (1970 census) ${ }^{a}$ & yes & yes & yes & yes & yes \\
\hline Immigrant $^{b}$ & yes & yes & yes & yes & yes \\
\hline \multirow[t]{3}{*}{$\mathrm{N}$} & 4883 & 3166 & 2793 & 3935 & 19756 \\
\hline & Mining & $\begin{array}{l}\text { Transport } \\
\text { and } \\
\text { communi- } \\
\text { cations }\end{array}$ & $\begin{array}{l}\text { Industry and } \\
\text { construction }\end{array}$ & Services & Military jobs \\
\hline & $\begin{array}{l}\text { Coefficient } \\
\text { (Robust SE) }\end{array}$ & $\begin{array}{l}\text { Coefficient } \\
\text { (Robust SE) }\end{array}$ & $\begin{array}{c}\text { Coefficient } \\
\text { (Robust SE) }\end{array}$ & $\begin{array}{c}\text { Coefficient } \\
\text { (Robust SE) }\end{array}$ & $\begin{array}{l}\text { Coefficient } \\
\text { (Robust SE) }\end{array}$ \\
\hline \multicolumn{6}{|l|}{ First stage } \\
\hline Eligibility age (years) & $\begin{array}{r}0.6991 \quad * * * \\
(0.0813)\end{array}$ & $\begin{array}{rl}0.7961 & * * * * \\
(0.0222) & \end{array}$ & $\begin{array}{r}0.7196 \quad * * * \\
(0.0102)\end{array}$ & $\begin{array}{rl}0.6375 & * * * \\
(0.0289) & \end{array}$ & $\begin{array}{r}0.8453 \quad * * * \\
(0.1021)\end{array}$ \\
\hline Educational level (1970 census) ${ }^{a}$ & yes & yes & yes & yes & yes \\
\hline Immigrant $^{b}$ & yes & yes & yes & yes & yes \\
\hline F-statistic & 307.96 & 262.78 & 722.29 & 74.85 & 30.96 \\
\hline Adjusted $\mathrm{R}^{2}$ & 0.1433 & 0.1929 & 0.1633 & 0.1369 & 0.2895 \\
\hline \multicolumn{6}{|l|}{ Second stage } \\
\hline Retirement age (years) & $\begin{array}{l}-0.0207 \\
(0.0287)\end{array}$ & $\begin{array}{r}0.0045 \\
(0.0072)\end{array}$ & $\begin{array}{r}-0.0027 \\
(0.0037)\end{array}$ & $\begin{array}{r}0.0150 \\
(0.0121)\end{array}$ & $\begin{array}{r}0.0035 \\
(0.0419)\end{array}$ \\
\hline Educational level (1970 census) ${ }^{a}$ & yes & yes & yes & yes & yes \\
\hline Immigrant $^{b}$ & yes & yes & yes & yes & yes \\
\hline \multirow[t]{2}{*}{$\mathrm{N}$} & 456 & 5529 & 25302 & 3168 & 149 \\
\hline & $\begin{array}{c}\text { [Missing } \\
\text { occupation] } \\
\text { Coefficient } \\
\text { (Robust SE) } \\
\end{array}$ & & & & \\
\hline \multicolumn{6}{|l|}{ First stage } \\
\hline Eligibility age (years) & $\begin{array}{r}1.2085 \quad * * * \\
(0.0353)\end{array}$ & & & & \\
\hline Educational level (1970 census) ${ }^{a}$ & yes & & & & \\
\hline Immigrant $^{b}$ & yes & & & & \\
\hline F-statistic & 319.58 & & & & \\
\hline Adjusted $\mathrm{R}^{2}$ & 0.3785 & & & & \\
\hline \multicolumn{6}{|l|}{ Second stage } \\
\hline Retirement age (years) & $\begin{array}{r}-0.0095 \\
(0.0050)\end{array}$ & & & & \\
\hline Educational level (1970 census) ${ }^{a}$ & yes & & & & \\
\hline Immigrant $^{b}$ & yes & & & & \\
\hline \multirow[t]{3}{*}{$\mathrm{N}$} & 5178 & & & & \\
\hline & $\begin{array}{c}\text { No general } \\
\text { education or } \\
\text { non-response }\end{array}$ & $\begin{array}{l}\text { Secondaty school } \\
\text { or similar }\end{array}$ & $\begin{array}{l}\text { Middle } \\
\text { school, } \\
\text { vocational } \\
\text { school or } \\
\text { similar }\end{array}$ & $\begin{array}{l}\text { High school } \\
\text { ("examen } \\
\text { artium") or } \\
\text { univerity/ } \\
\text { college }\end{array}$ & $\begin{array}{l}\text { [Missing } \\
\text { education] }\end{array}$ \\
\hline & $\begin{array}{l}\text { Coefficient } \\
\text { (Robust SE) }\end{array}$ & $\begin{array}{l}\text { Coefficient } \\
\text { (Robust SE) }\end{array}$ & $\begin{array}{l}\text { Coefficient } \\
\text { (Robust SE) }\end{array}$ & $\begin{array}{c}\text { Coefficient } \\
\text { (Robust SE) }\end{array}$ & $\begin{array}{l}\text { Coefficient } \\
\text { (Robust SE) }\end{array}$ \\
\hline
\end{tabular}


Postprint version

\begin{tabular}{|c|c|c|c|c|c|c|c|c|c|c|}
\hline Eligibility age (years) & $\begin{array}{r}0.8009 \\
(0.0084)\end{array}$ & $* * *$ & $\begin{array}{r}0.6885 \\
(0.0188)\end{array}$ & $* * *$ & $\begin{array}{r}0.6403 \\
(0.0132)\end{array}$ & $* * *$ & $\begin{array}{r}0.4222 \\
(0.0199)\end{array}$ & $* * *$ & $\begin{array}{r}0.7556 \\
(0.0719)\end{array}$ & $* * *$ \\
\hline Occupational group $^{c}$ & yes & & yes & & yes & & yes & & yes & \\
\hline Immigrant $^{b}$ & yes & & yes & & yes & & yes & & yes & \\
\hline F-statistic & 1031.33 & & 141.87 & & 244.55 & & 2286.45 & & 21.92 & \\
\hline Adjusted $\mathrm{R}^{2}$ & 0.2316 & & 0.1935 & & 0.1996 & & 0.1626 & & 0.1112 & \\
\hline \multicolumn{11}{|l|}{ Second stage } \\
\hline Retirement age (years) & $\begin{array}{c}-0.0014 \\
(0.0025)\end{array}$ & & $\begin{array}{r}0.0139 \\
(0.0071)\end{array}$ & & $\begin{array}{r}0.0020 \\
(0.00578)\end{array}$ & & $\begin{array}{r}0.0179 \\
(0.0160)\end{array}$ & & $\begin{array}{r}-0.0084 \\
(0.0127)\end{array}$ & \\
\hline Occupational group ${ }^{c}$ & yes & & yes & & yes & & yes & & yes & \\
\hline Immigrant $^{b}$ & yes & & yes & & yes & & yes & & yes & \\
\hline $\mathrm{N}$ & 47475 & & 7556 & & 13200 & & 4072 & & 2012 & \\
\hline
\end{tabular}

Note: $* p<.05 ; * * p<.01 ; * * * p<.001$

${ }^{a}$ Educational level in four categories plus missing.

${ }^{b}$ Immigrant background in three categories.

${ }^{c}$ Occupations in 10 groups plus missing. 
Table 6 Discrete time hazard DiD models of the effect of retirement eligibility on death in the age span 67-70 years. Results presented as average marginal effects.

\begin{tabular}{|c|c|c|c|c|}
\hline \multirow[b]{3}{*}{ Being eligible for retirement } & \multicolumn{4}{|c|}{$\begin{array}{l}\text { Average marginal effect } \\
\text { (Standard error) }\end{array}$} \\
\hline & Model 1 & Model 2 & Model 3 & Model 4 \\
\hline & $\begin{array}{l}-0.0001 \\
(0.0001)\end{array}$ & $\begin{array}{l}-0.0001 \\
(0.0001)\end{array}$ & $\begin{array}{l}-0.0001 \\
(0.0001)\end{array}$ & $\begin{array}{l}-0.0001 \\
(0.0001)\end{array}$ \\
\hline Monthly age FE & yes & yes & yes & yes \\
\hline Monthly birth cohort FE & yes & yes & yes & yes \\
\hline Immigrant background dummies ${ }^{a}$ & no & yes & yes & yes \\
\hline Occupational group dummies ${ }^{b}$ & no & no & yes & yes \\
\hline Education level dummies $(1960)^{c}$ & no & no & no & yes \\
\hline $\mathrm{N}$ (person months) & 4965809 & $\begin{array}{r}4965 \\
809\end{array}$ & $\begin{array}{r}4965 \\
809\end{array}$ & $\begin{array}{r}4965 \\
809\end{array}$ \\
\hline Pseudo $\mathrm{R}^{2}$ & 0.0019 & 0.0020 & 0.0050 & 0.0057 \\
\hline
\end{tabular}

